\title{
AN ANTHOLOGY OF THE DISTINGUISHED ACHIEVEMENTS IN SCIENCE AND TECHNIQUE. PART 40: THE SCIENTIFIC OPENING OF THE METHOD OF EXPLOSIVE IMPLOSION FOR THE OBTAINING ABOVE CRITICAL MASS OF NUCLEAR CHARGE AND UKRAINIAN «TRACK» IN THE «MANHATTAN» AMERICAN ATOMIC PROJECT
}

\begin{abstract}
Purpose. Preparation of short scientifically-historical essay about the prominent American scientist-chemist and physicist George Bogdan Kistiakowsky, having the Ukrainian "roots» and bringing in a considerable scientific and technical contribution to development and creation of the first atomic bombs in the USA. Methodology. Scientific methods of collection, analysis and analytical treatment of the opened scientific and technical information of world level in area of atomic and nuclear physics, physics of hyperpessure, applied electrophysics, modern experimental physics, atomic science and technology. Results. The stateof-the-art review of the state of basic scientific and technical problems, arising up before scientists and engineers at development and creation within the framework of the "Manhattan" American atomic project of the first standards of atomic bombs of the USA is resulted. Two basic methods of receipt in the a-bomb of above critical mass of the divided nuclear material of military load are described: method of "cannon-shot" and method of "explosive implosion". Basic information is resulted about the declassified scheme and construction decisions, applied scientists and specialists in the first atomic bombs of the USA. Technical information is indicated about basic ordinary hard chemical explosive matters (EM), atomic bombs of the USA of implosend type utillized in the first. Originality. Systematization of the scientific and technical materials devoted the basic results of pioneer nuclear researches in the USA and USSR in the period of 1940-th on a capture above all things for soldiery aims by intranuclear energy and to the offensive on a planet Earth of nuclear era known from the opened sources is executed. The important role of the scientific ukrainian origin of G.B. Kistiakowsky in development and creation in the National nuclear center of the USA Los-Alamos of laboratory of the first implosend atomic bombs of the USA. The large deposit of the American scientist is marked in area of physical chemistry, of theory and practice chemical EM G.B. Kistiakowsky in a fight for stopping in the world of race of armaments and nuclear disarmament. Practical value. Popularization and deepening for students, engineer and technical specialists and research workers of scientific and technical knowledges in area of nuclear physics, modern experimental physics, atomic science and technology, extending their scientific range of interests and further development of scientific and technical progress in human society. References 21 , figures 10.

Key words: history of creation in the USA and USSR of the first standards of nuclear weapon, atomic bomb, critical mass of nuclear explosive, nuclear explosion, methods of «cannon-shot» and «explosive implosion» for an atomic bomb, chemical explosive matter, scientific achievements, nuclear disarmament.
\end{abstract}

Приведен научно-исторический очерк о выдающемся американском ученом-химике и физике Дэсордже Богдане Кистяковском, имевщем украинские "корни» и внесшем огромный вклад в разработку и создание первых атомных бомб США. Благодаря его научным достиясениям в области изобретения новых химических взрывчатых веществ и успешному развитию им метода взрывной имплозии в 1945 году была реализована на практике теория ядерного взрыва. Отмечены усилия этого ученого в последние десятилетия его жсизни в борьбе за прекращение в мире гонки вооружений и ядерное разоружение. Библ. 21 , рис. 10.

Ключевые слова: история создания в США и СССР первых образцов ядерного оружия, атомная бомба, ядерный взрыв, метод взрывной имплозии и бомба, научные достижения, ядерное разоружение.

Introduction. The world history of mastery in the first half of the 20th century by outstanding scientists and engineers of the genus of human intranuclear energy and its further military-strategic use, because of its specificity and closeness, contains more than one dozen little-known, interesting and interesting for the general reader scientific and technical facts. One of such facts in 2015 was reported by our metropolitan newspaper «Zerkalo Nedeli» $[1,2]$. It dealt essentially with Ukraine (then in the early 20th century from the Russian Empire) George Bogdan (Georgy Bogdanovich) Kistiakowsky, an outstanding American expert in the field of physical chemistry and solid explosives, who made a huge contribution to the creation of the first US atomic bombs and practical implementation of the theory of nuclear explosion [3]. What exactly did the Ukrainian G.B. Kistiakowsky (Fig. 1), so valuable and important for the onset of the atomic era on our planet, do? We will try to follow below with the use of exclusively open sources and messages from the World Wide Web in a concentrated form of a brief scientific and historical essay to trace the milestones of the life and creative path of this legendary scientist of the United States, who stood at the very origins of the creation and creation of the most terrible weapons in the history of mankind.

1. The beginning of the way. George Kistiakowsky was born on November 18, 1900 in the family of Professor of law at Kiev University Bogdan Aleksandrovich Kistiakowsky and his wife Maria (nee Berenshtam) [4]. He received his secondary education in private schools in Kiev. In the autumn of 1918 he joined the White Army and until the autumn of 1920 participated in military operations. After the defeat of Wrangel's

(C) M.I. Baranov 
forces in the Crimea, he first came to Turkey, and then to Germany. In 1921 he entered the University of Berlin on Chemical Faculty, which he graduated from in 3.5 years. In 1925, under the scientific guidance of Prof. M. Bodenstein he successfully defended a Doctoral Thesis at this University on the topic of the problem of the decomposition of chlorine oxide with the help of a flux of light radiation [3]. In 1926, as a scholar of the International Committee for Education in Physical Chemistry, he was sent to the Princeton University (USA) for scientific internship [4].

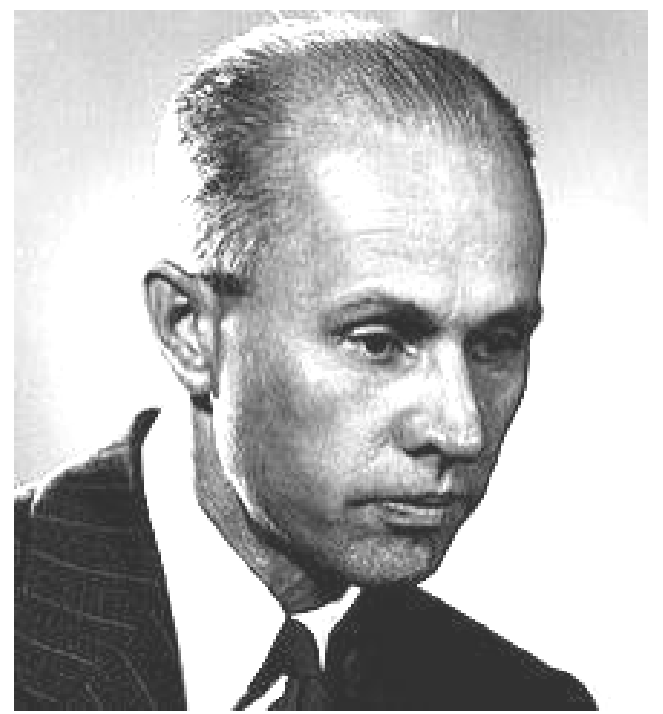

Fig. 1. Prominent American chemist and physicist George Bogdan Kistiakowsky (1900-1982), one of the main inventors and creators of the first atomic bombs of the USA of implosive type [3]

According to the results of the research, in 1928 he published his first scientific monograph «Photochemical Processes» in the United States, which brought the young scientist to fame in the field of photochemistry. Since 1930, as a Professor, he began teaching chemistry at Harvard University (Boston, USA), with whom he was associated for the rest of his life. In 1933 G.B. Kistiakowsky accepted US citizenship and began to bear a new name - George Bogdan Kistiakowsky. During the Second World War he dealt exclusively with military scientific and technical issues [3, 4]. He had an active civil position and was an ardent opponent of German fascism. Therefore, in those war years, this scientist concentrated all his physical, moral and creative forces on works directly aimed at the victory over Germany. Since 1941 G. Kistiakowsky became a member of the Committee on Atomic Energy of the National Academy of Sciences of the United States. In this Academy of Sciences of the USA he was elected for scientific merits in the field of studying chemical explosive matters (EM). In 1942, he headed the Department for the development and testing of conventional chemical explosives at the National Defense Research Committee of the United States [3, 4].

2. Manhattan Project of the USA. It is known that the pioneers of the nuclear era on the planet Earth were the two most powerful countries in the world - the US and the USSR. For this purpose, their most outstanding physicists, at first, developed theoretical models of nuclear-physical processes and nuclear warheads of a new type of weapons of enormous destructive power. Their scientists and engineers have conducted numerous experiments on physical and technical stands to determine a number of nuclear constants. Historically, in the practical creation of the first nuclear weapons (at the stage of work on the production of atomic bombs), large-scale issues have come to the fore, connected with the organization in these developed countries of a fundamentally new type of industry - the nuclear industry, which requires huge capital investments and completely new technologies for the production of fissionable nuclear materials, and other necessary for the realization of the unprecedented enormous scientific and military tasks of the accompanying materials of nuclear (super high) purity [5].

In the United States, to achieve this goal in the shortest time (with the first persons from the political leadership of the country and the outstanding physicists of the world on its territory constantly remembered similar searches in Germany for the creation of such a superweapon) after the signing by President Franklin Roosevelt on January 19, 1942 the American government, in complete secrecy, launched a decree on the conduct of work on the creation of an atomic bomb in the United States by the US «Manhattan» Atomic Project widely known to many of us [1-6]. Since the autumn of 1942, to intensify the whole complex of closed works and transfer them to a practical plane, this scientific and technical project of a huge military purpose was transferred directly to the American army. His administrative leader was appointed Brigadier General of the US Army 46-year-old Leslie Groves [5-7]. As a scientific supervisor of the project, from the autumn of 1943, at the request of L. Groves, a 39-year-old theoretical physicist from the University of California (Berkeley, USA), Professor Robert Oppenheimer (1904-1967) [5-8 ]. This scientistphysicist was simultaneously appointed director of the new National Nuclear Center of the United States, a super-secret Los Alamos Scientific Laboratory located in the desert area of New Mexico, which deals exclusively with the development and creation of the first atomic bombs in the USA [5-8]. In the Manhattan project, in fact, an international team of leading physicists and specialists from all over the world (naturally except physicists in the USSR and Germany), including 12 Nobel Prize Laureates in physics and chemistry, took part [7,9]. More than 130 thousand people were involved in the work of this project. All financial costs of the project were written off to the virtually existing Manhattan engineering district, whose command was General L. Groves (hence, obviously, according to the cover secret developed by the US secret services, and the name of this super-secret project took place). The incurred monetary costs for the implementation of this superproject for the period 19421945 amounted to a huge for those times the amount - 
about 2 billion USD (in current prices it is about 63 billion USD) [9]. Note that in 1944, the United States gross domestic product (GDP) was about 1499 billion USD [9]. For comparison, it should be noted that during this period Germany's GDP was about 437 billion USD, the USSR's GDP was 362 billion USD, Britain's GDP was 346 billion USD and Japan's was 189 billion USD. From these economic data it is clear that in 1944 the US GDP exceeded the GDP of Germany, the USSR, Great Britain and Japan combined. To this, it is necessary to add that the United States, after the occupation by the German troops of France in 1940 (before this event, France, with its world-famous school of nuclear physicists headed by Frederic Joliot-Curie, occupied the leading position in the scientific world on the Uranium problem) Concentrate from the Belgian Congo (countries in Central Africa) in the volume of about 1200 tons, as well as serious calculations by the UK on its own nuclear project «Tub Alloys» (supervisor of the work - Professor of physics J. Thompson) [9]. Here it is necessary to point out that the scientific group of J. Thompson, which included the French nuclear physicists H. Halban and L. Kovarski, the famous students of F. Joliot-Curie, already in July 1941 sent to the British government deeply developed materials on the creation of uranium atomic bomb, including the calculation of the critical mass of its nuclear explosive the uranium isotope ${ }_{92}^{235} \mathrm{U}$ [9]. Given the complex military situation in Britain (the constant German bombing and the danger of German invasion) and the shortage of «financial resources» for expensive scientific projects on the «foggy Albion», the leaders of the Western Allies in the anti-Hitler coalition in the war against Germany, F. Roosevelt and W. Churchill agreed to those severe the war years about the mutual exchange of secret information on the atomic superbomb. The proud British, figuratively speaking, «gritting their teeth» and realizing that by voluntary transfer to the Americans of their data on the new superweapons, they lose the «key» to world domination, after all, under pressure from external and internal circumstances, they were forced to give the US their developments of own nuclear weapons.

As for the German Atomic Project (the scientific supervisor of the works is the outstanding German theoretical physicist, Nobel Prize Laureate in physics for 1932 Werner Heisenberg (1901-1976)), despite her capture in 1940 at the concentrator in Oolen under the occupation of 1200 tons of uranium concentrate by Belgium [9], the shortage of highly qualified specialists (many hastily left the country) and the extremely inadequate financing of these works (about USD 10 million [9]) led to the collapse of their obsessive ideas on mastering the world's first intranuclear energy, the creation of the first atomic superbomb and victory over the USSR [7].

Concerning nuclear research of a military nature, bleached with heavy human and material and technical losses of the USSR, during this period, for several years, «to death» by belligerent conventional weapons against Germany with its considerable own and European resources, it is necessary to say that the Atomic Project of the USSR (the scientific supervisor of the work Professor Igor Kurchatov (1903-1960), which started with the instruction of the State Defense Committee of the USSR No. 2352 of September 28, 1942 «On the organization of work on uranium», due to poor financing and underestimation by the government of the strategic importance of this work till 20 August 1945 was carried out slowly. After this date, and the organization of the Special Committee of the USSR Council of Ministers (chairman - Marshal of State Security L.P. Beria, deputy chairman - People's Commissar of Ammunition ColonelGeneral B.L. Vannikov, Colonel-General A.P. Zavenyagin, members - Academicians of the USSR Academy of Sciences P.L. Kapitsa and I.V. Kurchatov) atomic work in the USSR acquired unprecedented in scope and intensity $[5,7]$.

Therefore, taking into account the other political, economic and scientific-technical data mentioned above and known to the author in general terms, it is quite possible to conclude that the United States during the military period of 1942-1945, in comparison with the opposing sides-parties of the Second World War, had the most favorable chances of succeeding first in the development and creation of the first atomic bombs. American scientists and experts, as pioneers in the nuclear arms race, went the hard way: they simultaneously created two fundamentally different models of atomic bombs - «uranium» based on the fissile uranium isotope ${ }_{92}^{235} \mathrm{U}$ and «plutonium» based on the fissile isotope of plutonium ${ }_{94}^{239} \mathrm{Pu}$ [2- 9].

2.1. The «gun shot» method to detonate the uranium nuclear charge of an atomic bomb. The basic scheme for constructing a uranium atomic bomb based on the "gun shot" method was set forth in the English report of the Thompson Committee, transmitted by the United States in the autumn of 1941 [9]. Its author was physicist William Parsons. This scheme provided for the creation of a critical mass (of the order of $60 \mathrm{~kg}$ [9]) in the neutron-fissioning isotope of uranium ${ }_{92}^{235} \mathrm{U}$ with the flow of an explosive chain nuclear reaction in it [10]. For this purpose, two cylindrical parts with subcritical masses were used in the uranium charge: «shell» and «target» [6, 11]. Uranium «shell» (a solid assembly of individual rings of a cylindrical bar from $90 \%$ enriched uranium ${ }_{92}^{235} \mathrm{U}$ ) with a conventional cannon barrel and a smokeless powder charge at a speed of about $350 \mathrm{~m} / \mathrm{s}$ was sent inside a hollow cylindrical uranium «target» (a composite structure of separate hollow cylinders from enriched to $80 \%$ of uranium $\left.{ }_{92}{ }^{235} \mathrm{U}\right)[9,11]$. With the full flight of the uranium «projectile» into the uranium «target», a supercritical mass of nuclear explosive was formed, in which a chain nuclear reaction of an explosive nature was initiated by means of a neutron fuse (external source of neutrons). For example, in the first American uranium atomic bomb «Little Boy» with a capacity of TNT equivalent of about 15 kilotons, exploded in the morning (at 09:16 am) on August 6, 1945 at an altitude of about 580 meters above the city of Hiroshima, Japan, the 
uranium «shell» of the nuclear charge (160 mm long and $100 \mathrm{~mm}$ in diameter) had a mass of about $26 \mathrm{~kg}$ (enriched to $89 \%$ of uranium ${ }_{92}^{235} \mathrm{U}$ ), and the uranium target of the nuclear charge $(160 \mathrm{~mm}$ in length, $100 \mathrm{~mm}$ in internal diameter and outer $160 \mathrm{~mm}$ in diameter) had a mass of about $38 \mathrm{~kg}$ (enriched to $80 \%$ of uranium ${ }_{92}{ }^{235} \mathrm{U}$ ) $[9,11]$. By the way, the neutron fuse in the first US uranium atomic bomb «Little Boy» was made on the basis of beryllium-polonium initiators emitting a neutron flux at the time of the supercritical mass of the fissioning uranium isotope ${ }_{92}^{235} \mathrm{U}$ in the cylindrical nucleus of the bomb $[9,11]$. To reflect the supercritical mass of the uranium isotope ${ }_{92}^{235} \mathrm{U}$ in the compressed state to reflect the neutron flux into the inner region of the bomb and retain it for the required time (of the order of $500 \mathrm{~ns}$ [5]) in order to allow at least 70 chain links of nuclear fission to occur in it [5], the cylindrical nucleus of this uranium The bombs were surrounded from the outside by massive cylindrical shells made of tungsten carbide (for immediately adjacent to nuclear explosives) and hardened steel (for the outer shroud) $[9,11]$. The total mass of such shells was about $2300 \mathrm{~kg}$. The cannon barrel, about 2000 $\mathrm{mm}$ in length, firmly fixed on a thick carbide sheath, together with the breech part, had a mass of about $450 \mathrm{~kg}$. Uranium «projectile» in a cannon barrel of the bomb developed speeds of up to $300 \mathrm{~m} / \mathrm{s}[9,11]$. As a result, the first US uranium atomic bomb «Little Boy» with a diameter of $0.7 \mathrm{~m}$ and a length of $3 \mathrm{~m}$ had a total weight of about 4,100 $\mathrm{kg}[5,9,11]$. Experimental data from the US confirmed that when the first uranium atomic bomb «Little Boy» was blasted, which killed about 170,000 residents and destroyed 62,000 buildings in Hiroshima for a moment, the energy released by the passage of a chain in the uranium isotope ${ }_{92}^{235} \mathrm{U}$ nuclear reaction, «inflates» the nuclear assembly of the bomb at a speed of about $1000 \mathrm{~km} / \mathrm{s}[7,11]$. Therefore, when it undermined, only up to $1.4 \%$ of $64 \mathrm{~kg}$ of the critical mass of the ${ }_{92}{ }^{235} \mathrm{U}$ enriched to not less than $80 \%$ of uranium had managed to react [11].

2.2. The method of «explosive implosion» to undermine the plutonium nuclear charge of an atomic bomb. Undermining the plutonium nuclear bomb of an atomic bomb based on the weapons-grade isotope of plutonium ${ }_{94}^{239} \mathrm{Pu}$ (Fig. 2), synthesized and isolated in 1941 by a group of American nuclear scientists led by Glenn Seaborg (for this important discovery in 1951, he was awarded the Nobel Prize for chemistry) [5, 12], with a subcritical mass of up to $6.2 \mathrm{~kg}$ using the "gun shot» method described in subsection 2.1 proved to be fundamentally impossible $[9,11]$.

The main reason for this was that the weapons-grade plutonium ${ }_{94}^{239} \mathrm{Pu}$ which is currently being produced commercially in the fuel elements of nuclear reactors in the long-term irradiation with neutrons of the natural uranium isotope ${ }_{92}^{238} \mathrm{U}$ contained in them [5, 10], is significantly larger (about 100 times $[6,11]$ ) by the neutron background (this fissile nuclear material is strongly «fonite» or «glows»).



Fig. 2. The unique view of two hemispherical blanks cast in a special metallurgical furnace is silver-white (on the left with a flat inner part, and on the right with a rounded outer part) of the subcritical mass of fissile nuclear material from weapons-grade plutonium ${ }_{94}^{239} \mathrm{Pu}$ used in the first US implosive atomic bombs «Trinity» and «Fat Man» [6]

Because of such a relatively large background neutron flux, even when the plutonium «projectile» approaches the plutonium «target» between them, a chain nuclear reaction starts prematurely, leading to inefficient separation of intranuclear energy in the zone of their «meeting». It is interesting to note the fact that I remembered for a lifetime the fact of the Soviet period from my own scientific biography, when at one time the author, while staying at the secret scientific center of the USSR at the world level - VNIITPh (Chelyabinsk-70), now called the Russian Federal Nuclear Center No. 2 (Snezhinsk), it was possible at one of the unique nuclear installations to see firsthand the controlled course of the chain nuclear reaction between two vertically approaching in the open air inside the thick lead detachable casings by massive uranium discs. Moreover, this reaction was accompanied by a visually visible intense sizzling (well, just like an electric corona!) glow of bluish-blue color in the section of the interdisk air gap up to $30 \mathrm{~mm}$ in length (now one can only guess at the intensity of neutron radiation in the zone of this air gap). Then, in order to avoid neutron irradiation, all observing this impressive nuclear-physical phenomenon were at a distance of about $10 \mathrm{~m}$ from the core behind a thick (thickness more than $100 \mathrm{~mm}$ ) leaded glass, providing our radiation protection. Returning again to the scientific subject of our nuclear physical examination, we point out that, from the practical application of such a scheme of detonation in a nuclear bomb of a plutonium nuclear charge, one nuclear «fizzle» was obtained [11]. For an effective nuclear «detonation» of the plutonium charge in an atomic bomb, using the «cannon shot» method, the speed of the connection of its (charge) parts should have been technically unattainable (more than $1 \mathrm{~km} / \mathrm{s}$ ) [11]. It should not be forgotten that the uranium isotope ${ }_{92}^{235} \mathrm{U}$ is better than the isotope of plutonium ${ }_{94}^{239} \mathrm{Pu}$ withstanding strong mechanical loads [11]. By the way, according to modern data, to improve the stability of physical properties and increase the compressibility (plasticity), the isotope of plutonium ${ }_{94}^{239} \mathrm{Pu}$ is doped with a small 
amount of gallium $31^{70} \mathrm{Ga}[11]$. That is why at the end of 1943 the work on the creation of the plutonium atomic bomb in the USA was at an impasse. And as it turned out in the future, it was the plutonium type of nuclear charge that determined the world's main path for the creation of all nuclear (atomic and thermonuclear) weapons. Scientists needed a fundamentally new technical solution to create and undermine the supercritical mass of the nuclear charge of an atomic bomb from weapons-grade plutonium ${ }_{94}^{239} \mathrm{Pu}[9,11]$.

And such a new scientific and technical solution in the Los Alamos Laboratory of the United States was first discovered in 1944. Its author was the American physicist Seth Neddermeyer [9]. He proposed a method of "explosive implosion» (this term derives from the English word «implosion» $[5,13])$, which involves, by compressing an explosive wave converging toward the center of the bomb from the explosive of chemical EM of plutonium nuclear explosives supercritical mass. According to this method of detonation of nuclear explosives from weapons-grade plutonium ${ }_{94}^{239} \mathrm{Pu}$, explosive charges from conventional chemical explosives (for example, from trinitrotoluene (TNT) or hexagen) are exploded from the outside all along the perimeter of this fissile nuclear material $[5,9,11]$. Numerous charges with chemical EM are activated by means of a system of electric detonators, triggered by a single trigger device. It was one thing to propose an implosive scheme for detonating the nuclear charge of an atomic bomb (yes, this was then certainly a revolutionary step in the field of atomic science and technology), and it is another thing to implement it practically. There were months of laboratory tests of such a scheme for building a plutonium atomic bomb, but there were no acceptable results.

And here, in the spring of 1944, the scientific leader of the «Manhattan» American Atomic Project R. Oppenheimer, and draws in full to the creation of an implosive atomic bomb of the leading US scientist in the development and testing of conventional chemical EM, Professor at Harvard University G. Kistiakowsky [9]. It should be noted that even before the above-mentioned period, practically since 1943, this American chemist has already performed some work in the framework of this superproject. In the spring of 1944, G. Kistiakowsky became the head of the Department $G$ in the Los Alamos Laboratory, engaged in EM and responsible for solving the problem of implosion reduction of plutonium nuclear charge of an atomic bomb [4, 9]. On the special importance, the scientific and technical level and the amount of work performed in this Department can be indicated by the fact that by the beginning of 1945, in the submission of G. Kistiakowsky, the collective was tense and with full dedication to working like-minded people, including about 600 scientists and engineers [2, 4].

Despite strict secrecy in all countries of the world, the devices of nuclear munitions, thanks to some declassified data on the construction of the first US atomic bombs, we can correctly from the positions of ultrahigh-pressure physics, nuclear and nuclear physicists and, as it turned out, electrophysics, to state the basic principles of their circuit-structural construction and operation [6, 11]. G. Kistiakowsky and his Department G had to develop a new spherical explosive shell and detonation system for its explosion to implosion the plutonium charge of the bomb, based on solid chemical EM which would provide a directed and growing to the center of the bomb, where a spherical charge was placed from weapons-grade plutonium ${ }_{94}^{239} \mathrm{Pu}$ with a subcritical mass, a spherical shock gas-dynamic wave [6]. Estimates made by G. Kistiakowsky showed that in order to achieve this goal, it is necessary to use both explosive and slow brisant chemical explosives in the explosive shell developed by him at the Los Alamos Laboratory of the USA. To do this, they created a new «slow» brisant chemical explosives (mixture of TNT (33\%), barium nitrate $(66 \%)$ and binder wax $(1 \%))$, called «baratol» and having a stable detonation velocity (propagation velocity in EM process of chemical decomposition [5, 13]) about $4 \mathrm{~km} / \mathrm{s}[3,6]$. The use of composition B (mixture of hexagene $(60 \%)$, TNT $(39 \%)$, and binder wax $(1 \%))$, which has a detonation velocity of up to $9 \mathrm{~km} / \mathrm{s}$, was suggested as a «fast» brisant chemical explosive in a plutonium atomic bomb $[5,6]$. A «slow» brisant chemical EM was used in the outer part of a massive explosive shell, and a «fast» brisant chemical explosive was used in its inner part adjacent to a spherical massive aluminum pusher (neutron absorber) [3, 6]. For the completeness of the complex gas-dynamic problem solved by G. Kistiakowsky 's team from the chemical-physical field of explosives, we note that the accuracy of assembling individual cast brizant lens parts of a spherical explosive shell was less than $1 \mathrm{~mm}$. In order to avoid inhomogeneities in the shock wave directed to the inside of the bomb, special requirements were imposed on the accuracy of spherical surfaces in individual cast brisant lens parts weighing up to $100 \mathrm{~kg}$ of this explosive shell with a total mass of up to $2600 \mathrm{~kg}[6,11]$. A massive explosive shell with its outer (outer subshell) and internal (internal subshell) parts together with its massive spherical aluminum pusher and its massive spherical uranium body (a neutron reflector made from a natural uranium isotope of ${ }_{92}^{238} \mathrm{U}$ ) had to perform a strictly symmetrical reduction small (up to $100 \mathrm{~mm}$ in diameter) and made in the form of hemispheres of nuclear charge from weapon plutonium $94{ }^{239} \mathrm{Pu}$ separated by a thin gold layer (up to 100 microns thick) $u$ with a subcritical mass located inside such a spherical nuclear-chemical «puff» and containing a miniature neutron beryllium-polonium initiator of a spherical shape inside itself $[6,7,11]$.

As a result of scientific research, G. Kistiakowsky together with his colleagues at the Los Alamos Laboratory in the USA in February 1945 proposed the final design of the explosive shell for the first plutonium atomic bomb forming the spherical shock gas-dynamic wave growing to its center. The outer and inner subshells of this explosive shell were made of 32 explosive cast lenses, 20 of which were hexagonal, and 12 were pentagonal $[6,11]$. These lenses, made by precise casting 
from the molten «slow» and «fast» brisant chemical EM described above, joined together on the basis of the manufacturing of the leather shell of all the known football for us, forming a spherical explosive assembly with a thickness of up to $420 \mathrm{~mm}$ and an outer diameter of up to $1300 \mathrm{~mm}[6,7,11]$. The total weight of such an explosive shell of a plutonium atomic bomb was about $2500 \mathrm{~kg}[6,11]$. A hollow aluminum pusher with a boron content of ${ }_{5}^{11} \mathrm{~B}$ (up to $40 \%$ ), designed to absorb neutrons emitted from the plutonium-uranium assembly and to reduce the pressure drop behind the front of the detonation wave in the explosive shell (this solution increased the pressure of the gas-dynamic wave that passed to the center) diameter of $460 \mathrm{~mm}$ had a thickness of about $115 \mathrm{~mm}$ and weighed up to $120 \mathrm{~kg}$ [6]. With this explosive shell design, the hollow uranium body of a plutonium atomic bomb from a natural uranium isotope ${ }_{92}^{238} \mathrm{U}$ designed to reflect and retain neutrons in its center, with a wall thickness of $70 \mathrm{~mm}$, had an outer diameter of $230 \mathrm{~mm}$ and a mass of about $120 \mathrm{~kg}$ [6]. The uranium body and the plutonium charge of the bomb formed its subcritical system. Therefore, with its up to $20 \%$ of the released intranuclear energy was accounted for by the fission reactions in the uranium shell of the bomb $[6,7]$. Note that during the implosion explosion of the shell of these brisant chemical EM which creates pressure in the hundreds of thousands of atmospheres in the central part of the bomb, a decrease in the diameter of the spherical plutonium charge (the «core» of the bomb) occurred 2.5 times, which led to an increase to five times taking into account the mass loss due to the evaporation of fissionable nuclear material) of the density of weaponsgrade plutonium ${ }_{94}^{239} \mathrm{Pu}$ and to the appearance in it of a corresponding decrease in its critical mass, up to five critical masses $[6,7,11]$. We point out that the initial diameter of the subcritical spherical parts of the plutonium charge of the bomb was $90 \mathrm{~mm}$, which ensured the presence of a subcritical mass of up to $6.2 \mathrm{~kg}$ $[6,7,11]$. To trigger nuclear fission reactions in weaponsgrade plutonium ${ }_{94}^{239} \mathrm{Pu}$ with the supercritical mass obtained, a neutron flux initiating them was needed. For this purpose, a spherical cavity with a diameter of $25 \mathrm{~mm}$ was made inside the hemispheres of the plutonium charge to accommodate a neutron initiator containing a hollow spherical beryllium shell $20 \mathrm{~mm}$ in diameter with a wall thickness of $6 \mathrm{~mm}$, inside of which was a beryllium liner $8 \mathrm{~mm}$ in diameter $[6,7,11]$. On the outer surface of the beryllium liner and the wedge-shaped slits made on the inner surface of the beryllium shell, first layers of nickel and gold were deposited, and then a thin layer of radioactive polonium ${ }_{84}^{210} \mathrm{Po}$ with a total mass of up to 11 $\mathrm{mg}[6,7,11]$. Thin layers of nickel and gold before implosive explosion of the shell from chemical EM protected the hollow sphere and the liner sphere of beryllium ${ }_{4}^{9} \mathrm{Be}$ from the action of $\alpha$ particles (helium isotope nuclei ${ }_{2}^{4} \mathrm{He}[10]$ ) emitted by the polonium nuclei ${ }_{84}^{210} \mathrm{Po}$. The neutron initiator was activated when a converging shock gas-dynamic wave was reached from an implosive explosion outside the chemical EM center of the plutonium charge of the bomb. At this moment, the neutron initiator was extremely rapidly destroyed and the mixing of the polonium ${ }_{84}^{210} \mathrm{Po}$ atoms with beryllium ${ }_{4}^{9} \mathrm{Be}$. The alpha particles emitted by the nuclei of ${ }_{84}^{210} \mathrm{Po}$ were absorbed in the beryllium ${ }_{4}^{9} \mathrm{Be}$ formed in the center of the charge of the radioactive mixture, the nuclei of which began to actively emit neutrons that acted on the fissionable weapons grade plutonium $94{ }^{239} \mathrm{Pu}$ with supercritical mass [6, 7]. As a result, a chain nuclear reaction of explosive type began to flow in the plutonium nuclear charge of the bomb.

2.3. Application of electric explosion of thin conductors for detonation of chemical EM in the first atomic bombs of the USA. In the first American plutonium atomic bombs, thin electrically exploding conductors (EEC) were used to accurately synchronize the detonation of electric detonators of their explosive shells (see subsection 2.2) [6, 7, 11]. The electric explosion of short segments of thin EEC, carried out with an allowance of up to $\pm 10 \mathrm{~ns}$ and causing the simultaneous operation of 32 electric detonators and the corresponding detonation of all 64 lenses from the chemical explosives of the outer and inner explosive subshells of the bomb, was produced by supplying, through numerous electrical cables, from one charged high-voltage capacitor bank of a pulse of a large damped sinusoidal current $[6,15]$. The weight of such a starting electrical device, together with a capacitor bank, was about $200 \mathrm{~kg}[6,7]$.

3. A great physical experiment of US nuclear scientists in the Alamogordo desert. Given the colossal scientific and technological complexity of developing reliable designs and manufacturing the world's leading nuclear weapons in the «metal», it can be argued quite reasonably that this kind of sinister (diabolical) weapons of mass destruction of everything on our planet is the result of the world's prior development of science and technology. And now the paradoxical apotheosis of the scientific and technical achievements of mankind in the 20th century by the will of the objective process of the development of our civilization should be the great physical experiment of American scientists and engineers, demonstrating for the first time to all the nuclear explosion in the desert region of the Earth the first experimental US plutonium atomic bomb «Trinity» and, accordingly, the release of huge energy reserves, enclosed in the microcosm of matter.

Undoubtedly, this unique demonstration was not for everyone, but only for 425 elected scientists and specialists who arrived on the eve of this historic event at the US military training ground in the Alamogordo Desert (New Mexico) where a steel tower (Fig. 3) was installed and the first prototype of a plutonium atomic bomb, codenamed «Trinity», was prepared for the explosion [7]. We will point out that in a number of sources this bomb is also called «Gadget» [14]. We will stop in our narrative on the first name of this bomb $[5,9]$. 


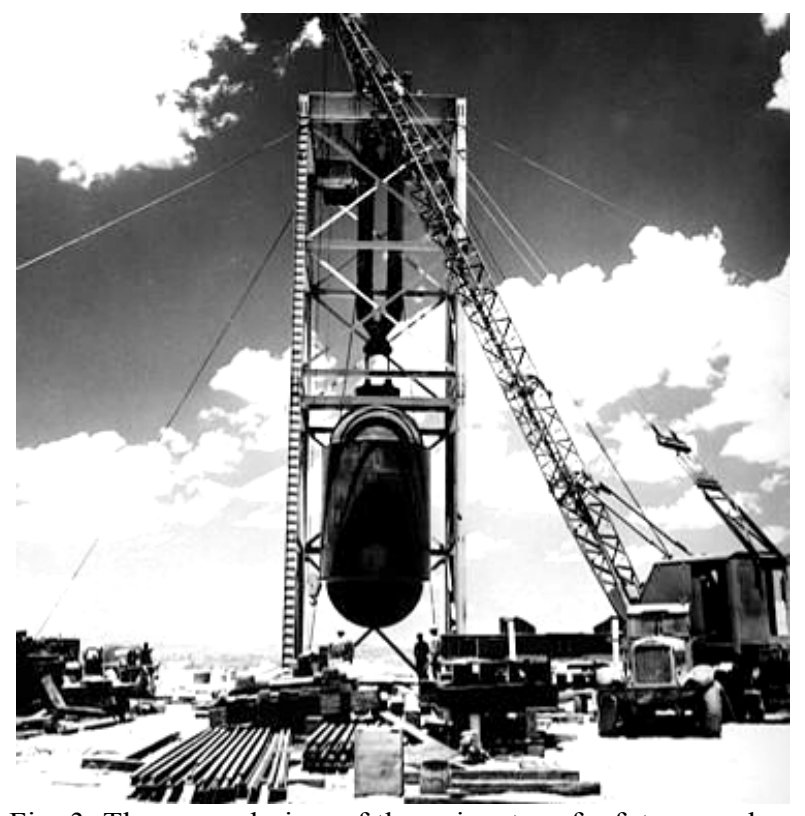

Fig. 3. The general view of the epicenter of a future nuclear explosion with a steel tower up to $30 \mathrm{~m}$ high, on top of which the first American plutonium atomic bomb «Trinity» (US military probe in the Alamogordo Desert, New Mexico) was moved there with the help of lifting equipment,

July 15, 1945) [7]

In my opinion, our attention deserves the reigning atmosphere among the authors-developers of this terrible from the universal positions and values of the American atomic bomb, as well as the leading scientists and specialists gathered at the US proving ground. Many of them intuitively realized that they were in step or from an unprecedented scientific discovery, or from an unprecedented catastrophe. For example, the Nobel Prize Laureate in physics for 1938, Enrico Fermi, who worked at the Los Alamos Laboratory on the creation of the first US atomic bombs, 5 believed that after the explosion of this atomic bomb from the present developers in a reinforced concrete bunker 10 miles away from its epicenter will not survive anybody [9]. G. Kistiakowsky argued with R. Oppenheimer for his monthly salary (USD 700) that the developed implosive explosion mechanism will work successfully and all will remain alive [9]. When declaring a 10 -second readiness, all those who were in the team bunker began to pray furiously, as last time, praying and remembering the words from the Gospel [9]: «...I believe! Lord, help my unbelief!» At that moment R. Oppenheimer could not take himself in hand: he was shaking with nervous tension [9]. Immediately after the explosion of the bomb and when a huge column of gas and smoke rose above the desert, on which a «nuclear mushroom» opened like a parachute (Fig. 4), R. Oppenheimer, violating the «grave» silence, exclaimed [8, 9]: «It's working!». Most of those present with him in the bunker were simply depressed and overwhelmed by this grandiose explosion and just remained silent. Then quickly came to life, G. Kistiakowsky loudly said [9]: «I am sure that when the end of the world comes, in the last millisecond of the Earth's existence, mankind will see exactly what we have just witnessed».

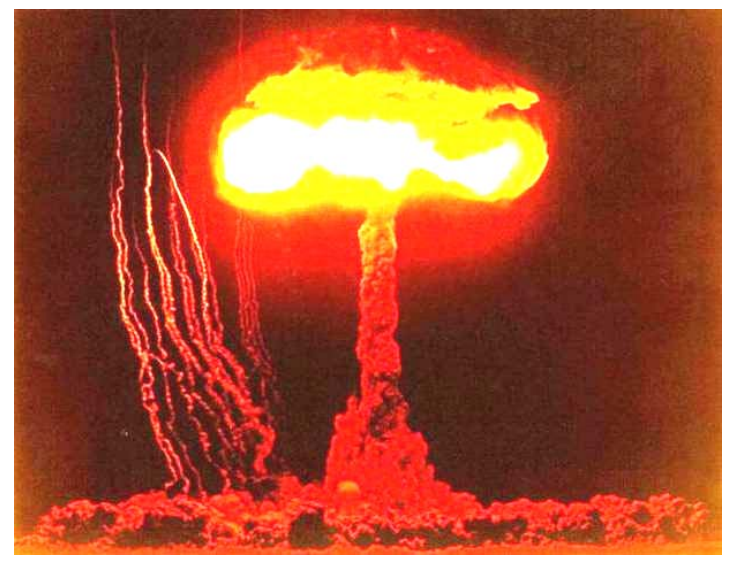

Fig. 4. External view of the «nuclear fungus» from the explosion of the first experimental plutonium atomic bomb of the United

States «Trinity» (the US military training ground in

Alamogordo, New Mexico, 05:30 am, July 16, 1945) [7]

In Fig. 4, to the left of the «nuclear fungus», winding «paths» of numerous channels of air electrical discharges accompanying the first nuclear explosion (NE) in the history of mankind are clearly visible. The formation of such electrical discharges in the air atmosphere is associated with the intensive separation of electric charges of both polarities in the zone of NE leading to the emergence of a high-ionized gas medium adjacent to the «nuclear fungus» of a high-power electromagnetic pulse, which along with penetrating radiation, light and shock wave is one of the main striking factors of nuclear weapons [11].

After the nuclear explosion of July 16, 1945, the first US experimental implosive atomic bomb «Trinity» with a plutonium «filling» subcritical mass of up to $6.2 \mathrm{~kg}$ with a trotyl equivalent of about $18 \mathrm{kt}$ from the steel tower (see Fig. 3), only a part of its melted reinforced concrete base remained (Fig. 5) [2, 5].

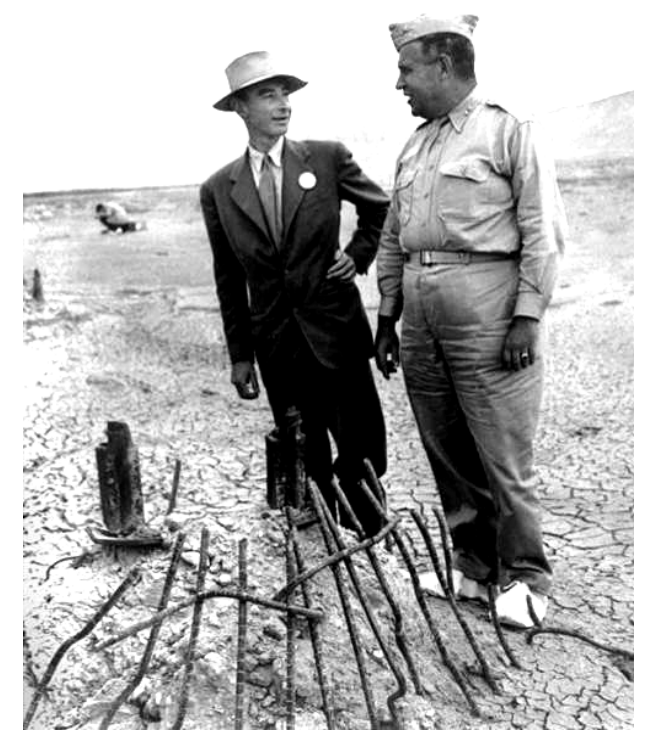

Fig. 5. Scientific and administrative leaders of the «Manhattan» US Atomic Project Robert Oppenheimer (left) and Leslie Groves (right) at the site of the nuclear explosion of the first implosive plutonium atomic bomb «Trinity» (the US military range $400 \mathrm{~km}$ south of Los Alamos, New Mexico, September 1945) [7] 
From the memories of the witness of the first in the modern history of mankind to test in the uninhabited area of the Earth nuclear weapons, the US Army General T. Farrell [7, 9]: «... This was something unprecedented. During the explosion, there was a stunningly beautiful and terrible game of gold, purple, purple, gray and blue colors. We felt ourselves to be small blasphemous creatures, swinging at the taming of forces that until then were subordinate only to the Most High. "In the radius of $1.5 \mathrm{~km}$ from the epicenter of the explosion of the first implosive plutonium atomic bomb «Trinity», the upper layer of sand melted, turning on the surface into a vitreous substance of greenish color - trinitite (this name was firstly artificially obtained on Earth substance, from the name of the American bomb that «gave birth» to it) [5-7]. The destructive power of the nuclear explosion carried out by the Americans so influenced the human psyche that no festive events and even parties were held for the successful testing of the first plutonium atomic bomb at the National Nuclear Center of the USA (Los Alamos) [9].

4. Awe-inspiring atomic bombing of the United States in $\mathbf{1 9 4 5}$ in Japanese cities. April 12, 1945, Franklin Roosevelt died and Harry Truman became the new President of the United States. The next day, April 13, 1945, US Secretary of Defense Henry Stimson was forced to report to the new US President and commander in chief of the US Army about the «Manhattan» superproject (surprisingly, as Vice-President, Truman did not know anything about him!) $[6,16]$. It was to this US president's share that fate had the right to make an important political decision about the first military use of nuclear weapons. On May 11, 1945, the Pentagon leadership, with the approval of its commander in chief, US President G. Truman, made a decision to deploy the first nuclear weapons attacks on peaceful Japanese cities Hiroshima, Kokure and Nagasaki [16]. An obligatory condition for carrying out atomic bombardment of these objects was the presence of a clear sky above them (first, for better aiming at a high altitude of the flight of an airplane (10-12 km), and, secondly, for photographing the results of unique bombardments). These bombardments were to take place on August 4, 1945. However, due to bad weather, the first of them (a nuclear strike in Hiroshima city) was postponed to August 6, 1945 [9, 16]. On the tragic consequences of the atomic bombing of August 6, 1945, Hiroshima, when the first uranium atomic bomb «Little Boy» was used with a power of TNT equivalent of about $15 \mathrm{kt}$, was mentioned above in Subsection 2.1 and [17]. In August 9, 1945, from the American B-29 strategic bomber (Fig. 6), to the Japanese city of Nagasaki, the plutonium atomic bomb «Fat Man» with a capacity of TNT equivalent of about $21 \mathrm{kt}$, due to the expansion in all directions at a speed of up to $1000 \mathrm{~km} / \mathrm{s}$ of its plutonium-uranium assembly, only $20 \%$ of the approximately $6.2 \mathrm{~kg}$ of the initial mass of the charge of weapons-grade plutonium ${ }_{94}^{239} \mathrm{Pu}$ in it had reacted (to share the nuclear image) $[6,18]$.



Fig. 6. The US B-29 strategic bomber used by the United States in 1945 to inflict eerie nuclear strikes on Japanese peaceful cities $[7,18]$

Due to the fact that the plutonium atomic bomb «Fat Man» having a length of $3.25 \mathrm{~m}$, a diameter of $1.5 \mathrm{~m}$ and a total weight of up to $4600 \mathrm{~kg}$, was blown up at an altitude of about $500 \mathrm{~m}$ on the outskirts of Nagasaki (the nuclear strike on the original goal - Kokurye was canceled due to the large cloudiness above it), the number of dead inhabitants of this peaceful city immediately after the nuclear explosion over it of this bomb (Fig. 7) was only about 90 thousand people [6,18 ]. The population and the government of Japan, after these two historical cases of the first US military use of nuclear weapons with horrific human losses and devastating consequences, were in an inexpressible shock. August 14, 1945 (recall that on August 9, 1945 the USSR declared war on Japan and with its victorious lightning-fast operations in the Far East practically compelled the land forces of the Kwantung Army of Japan with the number of up to 1 million soldiers and officers to surrender), the Emperor of Japan Hirohito after visiting the places nuclear bombing of the US Japanese cities begged for peace and said [9, 18]: «... Japan is forced to accept the conditions of the Potsdam Declaration». After that, on Sept. 2, 1945, on the American battleship «Missouri» authorized representatives of the USSR, the USA and Japan signed the Act of unconditional surrender and put a «fat point» in World War II [9, 18].



Fig. 7. The unique photograph by a Japanese amateur photographer who captured the explosion of the American plutonium atomic bomb «Fat Man» for history (11:02 am,

August 9, 1945, Nagasaki, Japan) [7, 18] 
5. Some recent information about the «leakage» of US atomic secrets in the USSR. All works on the US «Manhattan» Atomic Project were given the highest degree of secrecy [5, 6, 9]. The USSR from the very beginning of these works began to create a branched reconnaissance network around this superproject $[9,11]$. Not only Soviet agents worked for the USSR, but also American, British and Italian scientists and specialists involved in the implementation of a number of works on this project $[5,9]$. It is believed that, thanks to the active efforts of the intelligence agencies, the USSR foreign intelligence extracted about 12,000 sheets of A4 format from the US Atomic Project Manhattan with detailed information on the designs of the first US atomic bombs, information on the properties of the fissile and other radioactive materials used in them, and technologies the production of the fissile isotope of uranium ${ }_{92}^{235} \mathrm{U}$ and the fissile isotope of plutonium ${ }_{94}^{239} \mathrm{Pu}$ [5]. Therefore, certainly, not without reason, in the $1950 \mathrm{~s}$, trials took place in the USA against the spouses Julius and Ethel Rosenberg, David Greenglass (brother of E. Rozenberg) and Donald MacLeod, who gave the secret information about the US Atomic Project Manhattan [9] to the USSR. The United States established that an important agent recruited by the Soviet secret services was the English theoretical physicist Klaus Fuchs, who in September 1944 had become a direct participant in the development and creation of the first American atomic bombs [5, 9]. Over time, new names have sprung to the troubled «surface» of espionage in favor of the USSR: John Kernkross (from the famous "Cambridge Five») and Ted Hall, who «merged» US atomic secrets with Soviet intelligence [9]. Recently (in the spring of 2007) Russian President V.V. Putin appropriated the title of the Hero of Russia (posthumously) to the Soviet patriot-chemist Georges Koval, who graduated from the D.I. Mendeleyev Moscow Institute of Chemical Technology after the war who worked legally in the United States from the 1940s in the specialty and transmitted to the USSR valuable information about the activities in the closed nuclear cities of the USA Oak Ridge and Hanford on the production of fissile isotopes of uranium ${ }_{92}^{235} \mathrm{U}$ and plutonium ${ }_{94}^{239} \mathrm{Pu}[5,9]$.

It is generally believed that it was the data of $\mathrm{G}$. Koval who helped the scientific leader of the Atomic Project of the USSR Academician of the USSR Academy of Sciences I.V. Kurchatov in the beginning of 1945 to take a strategically correct decision on the development and creation in the USSR of the first plutonium atomic bomb under the working code name «First Lightning» $[9,11]$. At that time, the USSR was not able to «pull» the creation of two types of atomic bomb (uranium and plutonium) at once. Further events in the world nuclear arms race confirmed the full truth of such a responsible decision of a strong-willed and wise Soviet nuclear physicist. On August 29, 1949 (at 10:05 am) at the Semipalatinsk nuclear test site (Southeast Kazakhstan), the USSR successfully carried out in the desert area of its territory a test of the first Soviet plutonium atomic bomb with a capacity of about $22 \mathrm{kt}$ in TNT equivalent (Fig. 8). By and large, the Soviet plutonium atomic bomb under the final code name РДС-1 (this abbreviation according to the cover story of the Soviet special services came from the phrase «Stalin's Jet Propulsion» [19]) was in general a certain modification of our American nuclear plutonium atomic bomb by our nuclear physicists «Fat Man» [5, 20]. Having rechecked in the scientific laboratories the data obtained by the Soviet foreign intelligence on the construction of the first atomic bombs of the United States and convinced of their reliability, the political leadership of the Soviet country, in the person of its leader, Chairman of the USSR Council of Ministers I.V. Stalin and the scientific and administrative leadership of the Atomic Project of the USSR (represented by L.P. Beria and I.V. Kurchatov) in a narrow circle took a strictly closed decision on following the creation of the first Soviet atomic bomb by the already approved nuclear physicists and specialists in conventional EM by the US way of [19-21].

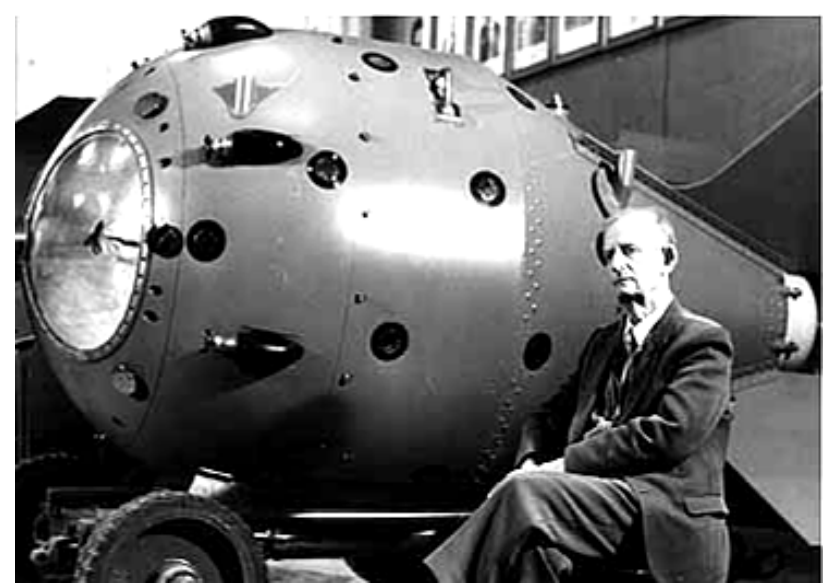

Fig. 8. External view of the first plutonium atomic bomb of the USSR, code-named РДС-1, with power of up to $22 \mathrm{kt}$ in TNT developed and created under the guidance of Yulij Borisovich Khariton, Academician of the USSR Academy of Sciences (1904-1996), who is sitting with a full-scale mock-up of the bomb (museum of theVNIIEPh now called the Russian Federal Nuclear Center No. 1, Arzamas-16, now called Sarov city, 1984, RF) $[5,16]$

For the Soviet Union, then, it was vital to ensure our own security by any means «gaining» time and quickly ending the US monopoly in the field of nuclear weapons. Therefore, more than 70 years after the beginning of the unprecedented in the USSR unprecedented in financial costs and the military-industrial epic for the creation of its own atomic bomb, the above-mentioned strategic decision of the USSR in the field of Soviet nuclear research and the production in the shortest possible time of the first atomic bomb samples.

6. Scientific, educational and political activities of G. Kistiakowsky after the «Manhattan» US atomic project. Immediately after the successful completion of the work at the Los Alamos Laboratory for the creation of the first atomic bombs of the United States, G. Kistiakowsky returned to the teaching and research 
work at Harvard University (Fig. 9) [2-4]. From 1947 to 1950 he was Head of the Department of Chemistry at this University in the United States. In the period 1953-1958 G. Kistiakowsky was a member of the US Defense Intelligence Agency Advisory Committee on Ballistic Missiles [2-4]. In 1957 he, as a well-known scientist in the field of physical chemistry and an extremely wellproven manager in the execution of the most important work on the Atomic Project, received an invitation from the US President D. Eisenhower (Fig. 10) to join the President's Council on Science and Technology. In this work, he did not stay long in the «shadow» and already in 1959 he headed this Council in the administration of the US president. In the period 1959-1961 G. Kistiakowsky also headed the Office of the President of the US Office of Science and Technology Policy. While in the White House, this scientist actively pursued and introduced into the consciousness of the country's political elite the policy of nuclear disarmament $[2,3,9]$.



Fig. 9. Professor of Harvard University G. Kistiakowsky after the successful completion of research in the Los Alamos

Laboratory of the United States on the atomic problem again for his favorite scientific and pedagogical work [3]

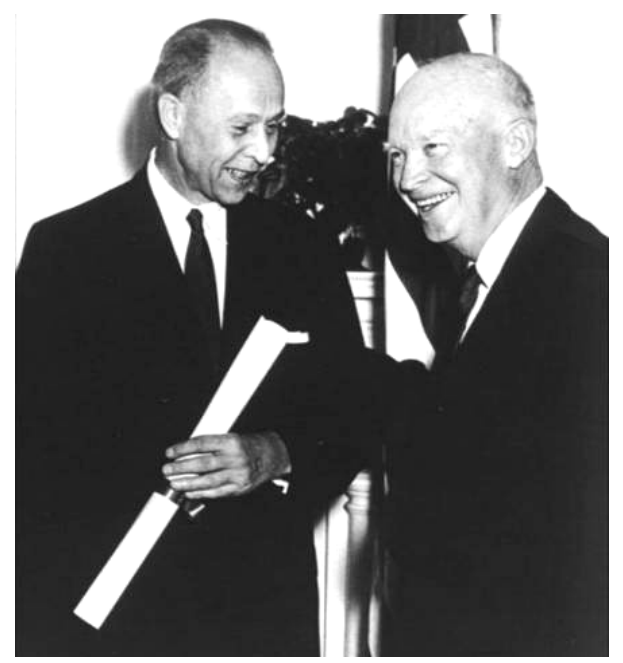

Fig. 10. US President D. Eisenhower (right) and his special assistant on science and technology G. Kistiakowsky (left) (Washington, White House, 1958) [3, 4]
Being in the post of adviser to the US president on science and technology until 1961, G. Kistiakowsky carried out consultations of the first person of the American state on coordination among various institutions of the country of a complex of scientific research and training of scientific personnel. In 1965, for scientific merit, he was elected Vice-President of the National Academy of Sciences of the United States. This honorable position he held until 1972 [9].

After retiring, G. Kistiakowsky actively joined in the fight against the proliferation of nuclear weapons in the world. In 1977 he headed the American Council for the Preservation of Life [3, 4]. It is believed that G. Kistiakowsky was in the United States one of the most successful Ukrainian scientists. At one time his main scientific developments in the field of physical chemistry and chemical EM were compared with the famous inventions of the Swedish engineer and businessman Alfred Nobel (1833-1896) [3-5, 12]. For outstanding scientific achievements, G. Kistiakowsky in the USA was awarded the Willard Gibbs Prize (1960), the National Scientific Medal of the USA (1967), the Priestly Medal (1972) and the Franklin Medal (1972) [2-4]. In 1982, his documents were prepared for the Nobel Peace Prize [9]. The famous American chemist and physicist (this famous native from the Ukraine), who achieved significant results in the development of physical chemistry, in the theory and practice of chemical EM, in the development and creation of the first nuclear weapons and in the struggle for world peace, died on December 7, 1982 [2-4, 9].

Conclusions. American physicist and chemist George Bogdan Kistiakowsky (1900-1982) of Ukrainian origin left behind a notable scientific «trace» not only in the field of physical chemistry in the development of new chemical explosives, but also in the field of ultra-highpressure physics and nuclear physics in the development and creation in the war period 1942-1945 in the USA within the framework of the «Manhattan»US Atomic Project Manhattan» of the first atomic bombs of the implosive type based on the isotope of plutonium ${ }_{94}^{239} \mathrm{Pu}$.

\section{REFERENCES}

1. George Bogdan Kistyakovsky and the project «Manhattan». Newspaper «Zerkalo nedeli», 2015, no.28-29. (Rus).

2. Available at: http://gazeta.zn.ua/personalities/dzhordzhbogdan-kistyakovskiy-i-proekt-manhetten (accessed 10 April 2014). (Rus).

3. Available

at:

https://en.wikipedia.org/wiki/George_Kistiakowsky (accessed 10 May 2012).

4. Available

at:

http://www.pseudology.org/science/KistyakovskyGB.htm

(accessed 23 March 2013). (Rus).

5. Baranov M.I. Antologiia vydaiushchikhsia dostizhenii $v$ nauke i tekhnike: Monografiia v 2-kh tomakh. Tom 1. [An anthology of outstanding achievements in science and technology: Monographs in 2 vols. Vol.1]. Kharkov, NTMT Publ., 2011. 311 p. (Rus).

6. Available at: http://ruatom.ru/milit/fm at tinian.jpg (accessed 03 October 2013). (Rus). 
7. Available at: www.infozoom.ru/pervaya-atomnayabomba.html (accessed 11 May 2013). (Rus).

8. Ruze M. Robert Oppengeymer $i$ atomnaya bomba [Robert Oppenheimer and the atomic bomb]. Moscow, Atomizdat Publ., 1965, 150 p. (Rus).

9. Available at: http://fraza.ua/analitics/26.09.15/230879/manhettenskij proekt ukrainskij sled chast 1 .html (accessed 12 June 2013). (Rus).

10. Kuz'michev V.E. Zakony i formuly fiziki [Laws and formulas of physics]. Kiev, Naukova Dumka Publ., 1989. 864 p. (Rus).

11. Available at: https://en.wikipedia.org/wiki/Nuclear_weapon (accessed 13 October 2010).

12. Khramov Yu.A. Istoriia fiziki [History of Physics]. Kiev, Feniks Publ., 2006. 1176 p. (Rus).

13. Bol'shoj illjustrirovannyj slovar' inostrannyh slov [Large illustrated dictionary of foreign words]. Moscow, Russkie slovari Publ., 2004. 957 p. (Rus).

14. Available at: http://www.2000.ua/vnomere/aspekty/persona aspekty/smog-vzorvat-atomnujubombu.htm (accessed 31 May 2013). (Rus).

15. Baranov M.I. Izbrannye voprosy elektrofiziki: Monografija $v$ 2-h tomah. Tom 2, Kn. 1: Teorija elektrofizicheskih effektov $i$ zadach [Selected topics of Electrophysics: Monograph in 2 vols. Vol. 2, book. 1: Theory of electrophysics effects and tasks]. Kharkov, NTU «KhPI» Publ., 2009. 384 p. (Rus).

16. Available www.dominating ru/atombomb/teory/history htm (accessed 23 October 2014). (Rus).

17. Jung R. Yarche tysyachi zvezd [Brighter thousands stars]. Moscow, Gosatomizdat Publ., 1961. 224 p. (Rus).

18. Available at: https://en.wikipedia.org/wiki/Atomic bombings of Hiroshima and Nagasaki (accessed 14 June 2009).

How to cite this article:

Baranov M.I. An anthology of the distinguished achievements in science and technique. Part 40: The scientific opening of the method of explosive implosion for the obtaining above critical mass of nuclear charge and Ukrainian «track» in the «Manhattan» American atomic project. Electrical engineering \& electromechanics, 2017, no.5, pp. 3-13. doi: 10.20998/2074-272X.2017.5.01.
19. Khariton Ju.B., Smirnov Ju.N. Mify i real'nost' sovetskogo atomnogo proekta [Myths and reality of the soviet atomic project]. Arzamas-16, USRIEP Publ., 1994. 72 p. (Rus).

20. Mikhailov V.N. Sozdanye pervoy sovetskoy yadernoy bomby [Creation of the first soviet nuclear bomb]. Moscow, Energoatomisdat Publ., 1995. 448 p. (Rus).

21. The USSR Atomic Project. Documents and materials: In 3 Vol. Ed. L.D. Ryabev. Vol. 1, 1938-1945: in 2 parts. Part 1. Min. of the RF for Atomic Energy; Ans. comp. L.I. Kudinova. Moscow, Science Publ., Fizmatlit Publ., 1998, 432 p.; Part 2: Moscow, Publishing House of MPhTI, 2002, 800 p.; Vol. 2 in 7 Books. Atomic bomb. 1945-1954: Book 1, 1999, 719 p.; Book 2, 2000, 640 p.; Book 3, 2003, 896 p.; Book 4, 2003, 816 p.; Book 5, 2005, 976 p.; Book 6, 2006, 896 p.; Book 7, 2007, 696 p. Russian Federal Atomic Energy Agency; Ans. comp. G.A. Goncharov. Sarov, RFNC-USRIEP, Moscow, Fizmatlit Publ. (Rus).

Received 29.06.2016

M.I. Baranov, Doctor of Technical Science, Chief Researcher, Scientific-\&-Research Planning-\&-Design Institute «Molniya» National Technical University «Kharkiv Polytechnic Institute», 47, Shevchenko Str., Kharkiv, 61013, Ukraine, phone +380577076841 , e-mail: baranovmi@kpi.kharkov.ua 